\title{
Makrostruktury społeczne w przedmiocie zainteresowania pedagogicznego
}

\begin{abstract}
Social macrostructures as the object of pedagogical interest
Abstract

The problem of upbringing is one of the inherent elements of social experience and has accompanied the human since the invention of the form of organization of social life, known as the state. Remedy for the experienced problems should be various initiatives and constructs unfortunately most of which often become ideology. In this article, author attempts to describe the concept of upbringing problems through its deconstruction and categorization of its components, which is aimed at presenting the implications for social reality, both contemporary and historical.
\end{abstract}

\section{Keywords}

macrostructures, society, social problems

W zasadzie taka makrostruktura społeczna, którą określa się mianem społeczeństwa: narodowego, państwowego, globalnego - w sensie poznawczym interesuje głównie naukę socjologiczną, stanowiąc zasadniczy przedmiot jej naukowej deskrypcji i eksplikacji1. W znacznej mierze, i w odnośnym aspekcie, mieści się ona

\footnotetext{
1 To, czy zasadniczym przedmiotem nauki socjologicznej jest struktura zwana społeczeństwem, stanowi ciągle żywy spór reprezentantów tej dyscypliny, skłaniających się zwłaszcza w konstruowanej autorsko jego teoretycznej interpretacji do określania go ogólnym mianem rzeczywistości społecznej lub jakiegoś jej aspektu, dominującej postaci czy fragmentu, tak czy inaczej konstruowanej jej struktury i dynamiki. Uzasadnienia tej tezy znajdujemy np. w toku lektury: P. Baert, F. Carreira da Silva, Teorie społeczne w XX wieku i dzisiaj. Kraków 2013; A. Jasińska-Kania i in. (red.), Wspótczesne teorie socjologiczne, t. I i II, Warszawa 2006; A. Manterys, J. Mucha (red.), Nowe perspektywy teorii socjologicznej. Wybór tekstów, Kraków 2009. Porównaj także: M. Ziółkowski, Teoria socjologiczna a transformacja społeczeństwa polskiego, Warszawa 2015 i wiele innych. Przeglądu socjologicznych definicji społeczeństwa dokonuje m.in. B. Misztal, Teoria socjologiczna a praktyka społeczna, Kraków
} 
w przedmiocie zainteresowania poznawczego także: geografii społecznej, demografii, ekonomii społecznej i niewątpliwie kilku innych dyscyplin, subdyscyplin naukowych, jak również dociekań o charakterze filozoficznym i ideologicznym jeśli to rozróżnienie uważamy za zasadne i pożyteczne poznawczo.

Poza ujawnianiem w szeroko pojętej wiedzy naukowej poznawczego zainteresowania rzeczywistością społeczną, miano dociekania jej istoty i wyobrażanego, zwłaszcza postulowanego kształtu rozmaicie uzasadnianego, zyskują również rozliczne postacie jej projektowania o charakterze globalnym, względnie aspektowym bądź wycinkowym. Tu właśnie spotykamy refleksje, rozstrzygnięcia i projekcje natury filozoficznej, teologicznej, ekonomicznej, politologicznej, ale i socjologicznej praktykowanej w postaci konstruowania tak zwanych utopii socjologicznych ${ }^{2}$.

Inicjatywy i konstrukty projektowe odnoszące się do szeroko pojętej rzeczywistości społecznej, najogólniej rzecz ujmując, ujawniają wszelkie znamiona przypisywane ideologii. Bowiem każdy z takich autorskich projektów „urządzania” rzeczywistości społecznej zyskuje wątpliwe, a więc mniej przekonywające uzasadnienie naukowe spodziewanego czy deklarowanego w nim sprawstwa, możliwego do zweryfikowania właśnie dopiero w próbach ich praktycznej realizacji. Próby te najczęściej ujawniają zawodność zawartej w nich obietnicy - remedium - na doświadczane aktualnie (i najczęściej w historii danego społeczeństwa narodowego czy/i państwowego) rozliczne problemy, którym w XX wieku przydano miano problemów społecznych.

Problemy społeczne, tak jak je obecnie identyfikujemy w dyskursie naukowym $^{3}$, niekoniecznie ujawniane i uświadamiane, bądź skrywane czy/i nierozpoznane, towarzyszą kondycji ludzkiej w zasadzie od czasu wynalezienia i praktykowania takiej formy organizacji życia społecznego, którą określa się mianem

\footnotetext{
2000, r. 2: Jak zdefiniować „społeczeństwo”?. Także J. Modrzewski, Społeczeństwo, [w:], T. Pilch (red.), Encyklopedia Pedagogiczna XXI wieku. T. 5, Warszawa 2005.

${ }^{2} \mathrm{~W}$ nauce socjologicznej jako dyscyplinie podstawowej w zasadzie od początku jej uprawiania (również w jej wersji filozofującej) uformowała się taka jej postać, która przybrała cechy refleksji i projekcji prakseologicznej i to trojakiego rodzaju: w odniesieniu do makrostruktury społecznej postać tak zwanych utopii socjologicznych (np. marksowska koncepcja porządku socjalistycznego czy komunistycznego), w odniesieniu do rozmaitych komponentów struktury społecznej, postać tak zwanej inżynierii społecznej (np. projekcji instytucji oświatowych, sprawowania władzy, organizacji środowiska lokalnego itp.), w odniesieniu do podmiotowo i/lub grupowo doświadczanych problemów egzystencjalnych - postać socjotechnik (np. socjoterapii, aktywizacji podmiotów społecznych itp.). Patrz np. Z. Bauman, Socjalizm. Utopia w działaniu, Warszawa 2010.

${ }^{3}$ Np.: J.M. Henslin, Social Problems, Sixth edition, New Jersey 2003; J.J. Macionis, Social Problems, Upper Saddle River, NJ 2011; R.K. Merton, R. Nisbet (red.), Contemporary Social Problems, New York 1971; K.J. Neubeck, M.A. Neubeck, Social Problems: A Critical Approach, New York 1997; E. Rubington, M.S. Weinberg (red.), The Study of Social Problems: Seven Perspectives, New York 2003 i wiele innych.
} 
państwa ${ }^{4}$. To właśnie ona, ta forma organizacji życia społecznego w jej historycznej zmienności i dokuczliwości - i z tej przyczyny - inspirowała filozofów i kreatorów systemów religijnych, już w czasach starożytnych, do konstruowania i upowszechniania wizji państwa doskonałego, godzącego w zamyśle ich twórców interesy z założenia wszystkich jego obywateli, względnie wyzwalała dążenia ku tworzeniu poza- i/lub ponadpaństwowych organizacji życia społecznego, zwłaszcza w postaci społeczności składających się z wyznawców i mniej lub bardziej zinstytucjonalizowanych struktur religijnych, funkcjonujących autonomicznie, przynajmniej do czasu ich fuzji z organizacją państwową, względnie przejęcia przez nie władzy na okupowanym terenie (np. kontynencie europejskim czy azjatyckim) $)^{5}$.

Idea sprawiedliwego, szczęśliwego, spokojnego, ustabilizowanego materialnie przeżywania przez ludzi swojej egzystencji w warunkach optymalnie urządzonego życia społecznego towarzyszy więc refleksji filozoficznej, teologicznej - ideologicznej od zarania jej uprawiania do chwili obecnej, zyskując w zasadzie znaczną akceptację i ujawniając powszechną niemoc w podejmowanych próbach jej osiągania. Zwłaszcza w sytuacji owej fuzji teologicznego systemu wiedzy i teologicznej organizacji życia społecznego z jego państwową instytucjonalizacją i usprawiedliwiającą ją ideologią podbudowaną także teologicznie (ustrój dowolny z teokratycznym uzasadnieniem), obecność problemów w doświadczeniu społecznym znajduje mocne ulokowanie i usprawiedliwienie wolą Najwyższego i z tej przyczyny czyniąc egzystencję ludzką w zasadzie fatalistyczną.

Niejednokrotnie na ten aspekt owej fuzji zwracano uwagę zwłaszcza w próbach konstruowania czy projektowania „odczarowanych” wizji ładu społecznego i poszukujących realnych, tu - „ziemskich” - przyczyn jego dokuczliwości oraz możliwości ich sukcesywnego, efektywnego obchodzenia czy przezwyciężania ${ }^{6}$.

Przeświadczenie o deterministycznej i ewolucyjnej, naturalistycznej niejako istocie, postaci i przyczynie(-ach) zmienności form życia społecznego i jego struktury legło u podstaw - jak wiadomo - jego oświeceniowej wizji, rozwijanej

${ }^{4}$ Patrz m. in.: J.C. Scott, Jak udomowiono człowieka. U początków historii pierwszych państw, przekł. F. Tryl, Warszawa 2020.

${ }^{5}$ Mam tu na uwadze autorskie wizje państwa doskonałego zainicjowane przez Platona w dziele: Państwo (Warszawa 1948), i szereg innych, w tym tak zwanych „królestw bożych” oferowanych przez inicjatorów ruchów religijnych i pozornie realizowanych np. przez władzę kościelną w Europie, a obecnie realizowane po znacznej części w wybranych krajach świata i tworzonych spontanicznie w nich enklawach społecznościowych, jak np. założona w 1971 roku przez hippisów Christiania w opuszczonych w centrum Kopenhagi koszarach marynarki wojennej (H. Cyrzan, O potrzebie utopii, Toruń 2004) czy realizowany projekt miasta-państwa - Auroville położonego w pobliżu Zatoki Bengalskiej w Indiach (K. Boni, Auroville. Miasto z marzeń, Warszawa 2020).

${ }^{6} \mathrm{~Np}$. w koncepcji państwa o ustroju socjalistycznym K. Marksa i F. Engelsa czy państwa o ustroju demokratycznym w wersji agonistycznej (patrz m.in. Ch. Mouffe, Paradoks demokracji, Wrocław 2005). 
od połowy XIX wieku w kilku dyscyplinach naukowych, a zwłaszcza w nurtach czy odmianach nauki socjologicznej ${ }^{7}$. To w tym nurcie (dyskursie) naukowej refleksji o życiu społecznym podejmowano niejednokrotnie próby skonstruowania teoretycznych wizji (modeli) poszukujących i wskazujących przyczyny - warunki - osiągania, w zbiorowych formach egzystencji ludzkiej, stanu względnej jej doskonałości - takiego, w którym jest ona konsekwencją:

- podejmowania racjonalnych decyzji, wspieranych przesłankami empirycznymi, nie mitycznymi czy interesownymi, a nierzadko wręcz patologicznymi;

- osiągnięcia konsensusu w postrzeganiu i akceptowaniu interesów rozmaitych podmiotów sceny politycznej i woli ich uwzględniania w procedurach decyzyjnych;

- ogólnego stanu kompetencji komunikacyjnej - stanu adekwatnej do zaistniałej sytuacji świadomości wiedzy o istocie doświadczanych problemów i możliwości jej zrozumienia, zaakceptowania, porozumienia w jej przezwyciężaniu i jej zastosowania w tych procedurach;

- ujawniania przez ośrodki decyzyjne stałej troski o zachowanie czasu spokoju, ładu i racjonalnego rozwoju aktualnie doświadczanego i rokującego pomyślnie w bliższej i dalszej perspektywie, a więc troski o bezpieczeństwo zewnętrzne i wewnętrzne społeczeństwa zorganizowanego w państwo;

- rzeczywistej troski ujawnianej przez te ośrodki o racjonalne, naukowo uzasadnione i w porę zastosowane działania ubiegające, względnie ostrzegające społeczności przed destrukcyjnymi zdarzeniami natury;

- racjonalnej gospodarki zasobami własnymi i pozyskiwanymi w drodze wymiany, zakupu czy odstąpienia9.

Niewątpliwie takich koncepcji (wizji, projekcji) efektywnie funkcjonującego państwa i towarzyszących im warunków pomyślnego radzenia sobie z doświadczanymi aktualnie problemami społecznymi jest więcej i są one w każdej teoretycznej koncepcji czy propozycji ich rozwiązywania mniej lub bardziej skrupulatnie wskazywane, tworząc kompleks tak zwanych wymogów sprawnego czy pomyślnego funkcjonowania społeczeństwa, postrzeganego, w jego teoretycznej wizji, jako swoistego systemu, szczególnej całości ulegającej już rozpoznanym em-

7 Patrz m.in.: S. Amsterdamski, Nauka, [w:], A. Kłoskowska, S. Krzemień-Ojak (red.), Encyklopedia kultury polskiej XX wieku, Wrocław 1991; F. Znaniecki, Nauki o kulturze, Warszawa 1971; J. Szacki, Historia myśli socjologicznej, Warszawa 2021.

${ }^{8}$ J. Habermas, Teoria działania komunikacyjnego, Warszawa 1999.

9 Patrz m.in.: M. Weber, Economy and Society, Berkeley, CA 1978; R. Dahrendorf, Klasy i konflikt klasowy w społeczeństwie przemysłowym, Kraków 2008; czy uważna lektura stosownych partii tekstu cytowanej monografii J. Szackiego, Historia myśli socjologicznej..., op. cit. 
pirycznie mechanizmom swojego istnienia i rozwoju ${ }^{10}$. Jednak wiedza o ich sprawczej roli - mimo jej upowszechniania - nie znajduje, jak dotychczas, skutecznego zastosowania w procedurach decyzyjnych ośrodków sprawujących władzę w wymiarze ogólnospołecznym i lokalnym $z$ wielu przyczyn, zarówno intencjonalnych (politycznych - sprawowanie władzy politycznej najczęściej nie polega na kompetentnym rozwiązywaniu problemów społecznych, lecz dynamicznej realizacji interesów partyjnych czy mafijnych grup, klik czy partii sprawujących władzę), jak i sytuacyjnych, określanych mianem obiektywnych, na które polityk ma niewielki lub żaden wpływ.

Wszystko to sprawia, że problemy społeczne są udziałem permanentnego doświadczenia zarówno całych społeczeństw państwowych, jak i ich struktur lokalnych ${ }^{11}$, stając się niejednokrotnie argumentem uzasadniającym propozycje zaniechania kontynuacji państwowej organizacji życia społecznego (koncepcje anarchizujące) na rzecz wzmacniania i autonomizowania struktur samorządowych ${ }^{12}$.

Wśród wielu z tego rodzaju problemów sytuuje się także społeczny problem wychowania z jego licznymi odmianami, zmienną dynamiką swojej struktury, przestrzennej ekspozycji i podmiotowo-przedmiotowych konsekwencji, skłaniając zarówno organa władzy państwowej, jak i samorządowej, do podejmowania mniej lub bardziej udanych praktyk jego pomyślnego rozwiązywania, wyzwalając także rozliczne inicjatywy społeczne zmierzające często bezskutecznie do łagodzenia lub ograniczania jego dysfunkcji, czyli uznanych społecznie w danym miejscu i czasie jako negatywnych skutków aktualizującego się, a szeroko pojętego, procesu wychowania (socjalizacji), wymagających podjęcia czynności naprawczych, reformatorskich, reedukacyjnych czy resocjalizacyjnych ${ }^{13}$.

${ }^{10}$ M.in.: N. Luhmann, Systemy społeczne, Kraków 2007; T. Parsons, System społeczny, Kraków 2009. W odniesieniu do rodzimej rzeczywistości polityczno-ustrojowej wskazuję na nie w artykule: $Z($ dez)integrowanie społeczeństwa - istota zjawiska i problemu w perspektywie strukturalno-funkcjonalnej, „Pedagogika Społeczna” 2017, nr 4. Porównaj także: P. Baert, F. Carreira da Silva, Teorie spoteczne..., op. cit., r. II.

${ }^{11}$ Patrz m.in.: M. Malikowski (red.), Problemy społeczne w okresie zmian systemowych $w$ Polsce, Rzeszów 1997; A. Nowak, E. Wysocka, Problemy i zagrożenia społeczne we wspótczesnym świecie, Katowice 2001; L. Miś, Problemy społeczne. Teoria, metodologia, badania, Kraków 2007; L. Miś, M. Nóżka, M. Smagacz-Poziemska, Nasze problemy. Bieda i bezrobocie we współczesnym społeczeństwie polskim, Kraków 2011; L. Miś, Problemy społeczne Grupy Wyszehradzkiej, Kraków 2019. Świetnie owo lokalne zakleszczenie się problemu społecznego w odniesieniu do edukacji przedszkolnej ukazali autorzy tekstów zredagowanych przez Marię Theiss w monografii: Lokalne obywatelstwo społeczne w polityce społecznej. Przykład wychowania przedszkolnego, Warszawa 2018.

${ }_{12}$ M.in. P. Kropotkin, Pomoc wzajemna, Poznań 2006.

${ }^{13}$ Szeroko pojęty proces wychowania wiedzie nie tylko do skutków godnych i zyskujących powszechną społeczną akceptację w danym układzie społecznym, lecz także do takich, jakie zyskują ją tylko w poszczególnych rodzinach, grupach rówieśniczych, w sektach i mniejszościowych społecznościach wyznaniowych czy np. w strukturach uznanych za patologiczne czy przestępcze, a mamy 
Doświadcza ich również społeczeństwo polskie w swoim czasie minionym, aktualnym i zapewne w swojej bliższej i dalszej perspektywie historycznej (pokoleniowej), mimo deklarowanych i faktycznie podejmowanych przez władze państwowe i samorządowe prób ich ograniczania czy „naprawiania” samego mechanizmu socjalizacyjnego-wychowawczego ${ }^{14}$.

Rozwiązywanie, mniej lub bardziej pomyślne, społecznego problemu wychowania to zasadnicza funkcja i zadanie tego podsystemu systemu społecznego (społeczeństwa globalnego), który określa się najczęściej mianem podsystemu kulturowego, w strukturze którego lokuje się z kolei podsystem zwany wychowawczym ${ }^{15}$. Zanim jednak ujawnimy jego znamiona, należy zwrócić uwagę na to, iż zasadniczą funkcją podsystemu kulturowego systemu społecznego jest uruchamianie mechanizmów gwarantujących wytwarzanie i zachowanie, w wymiarze historycznym,

tu na uwadze także rozliczne podmiotowe i grupowe kulturowe odmienności ujawniane w substrukturach i indywidualnych zachowaniach społecznych w tym układzie. Właśnie owe kulturowe odmienności stanowią przedmiot zainteresowania i troski pedagogów „pograniczy” kulturowych poszukujących i optujących za ich akceptacją czy tolerancją. Patrz m.in.: M. Sobecki, D. Misiejuk, J. Muszyńska, T. Bajkowski (red.), Człowiek pogranicza. Wyzwania humanistycznej edukacji, Białystok 2019. Odrębnym zagadnieniem godnym rozważenia jest identyfikowanie funkcjonujących w danym układzie społecznym jeszcze tolerowanych czy akceptowanych w nim granic podmiotowej oryginalności, indywidualności, przyzwolenia na społeczną obecność tak zwanych osób niekonwencjonalnych (nonkonformistów). M.in.: M. Jacyno, Kultura indywidualizmu, Warszawa 2007. Warto w tym względzie jeszcze sięgnąć do: J. Szmatka, Jednostka i społeczeństwo. O zależności zjawisk indywidualnych od społecznych, Warszawa 1980.

${ }_{14}$ Patrz m.in.: J. Modrzewski, Studia i szkice socjopedagogiczne. Aktualia, Kalisz-Poznań 2012, r. V: Wychowanie jako problem społeczny - jego istota i dynamika. Wychowanie identyfikowane w kategoriach problemu społecznego traktuję jako swoistą społeczną powinność, jako rzecz do koniecznego, permanentnego zrobienia, jeśli społeczeństwo identyfikujące się kulturowo, narodowo, państwowo, zatroskane kontynuacją swojej historii pragnie zachować w jej kolejnych odsłonach swoją tożsamość kulturową, suwerenność polityczną i dynamikę rozwojową (cywilizację). Może ją lokować i realizować społecznościowo (lokalnie, etnicznie), terytorialnie (kraj, rejon), kontynentalnie (Europa, Ameryka), a w dalszej perspektywie być może globalnie, chociaż skala aktualnego zróżnicowania cywilizacyjnego i politycznego społeczeństw nawet kontynentalnych i wyzwolone nią napięcia taką perspektywę, jak dotychczas, czynią wielce wątpliwą.

${ }^{15} \mathrm{~W}$ koncepcjach tak zwanego podejścia systemowego społeczeństwo państwowe identyfikuje się jako system społeczny (globalny, bazowy), na który składają się cztery jego zasadnicze podsystemy: sprawowania władzy (podsystem polityczny, decyzyjny), ekonomiczny (gospodarczy), bezpieczeństwa zewnętrznego i wewnętrznego oraz podsystem kulturowy, w którym lokuje się z kolei jego podsystem wychowania - socjalizacji. Wszystkie owe tak czy inaczej wyróżnione podsystemy są ze sobą zintegrowane zawsze na określonym poziomie - im wyższym, tym system społeczny funkcjonuje sprawniej, im niższym, tym system społeczny może być zagrożony w swojej perspektywie egzystencjalnej. Nad sprawnością systemu społecznego „czuwają” tak zwane mechanizmy obronne - serwomechanizmy - wśród których lokuje się także mechanizm wychowania - socjalizacji, skłaniający F. Znanieckiego do określenia społeczeństwa narodowego mianem wychowującego. F. Znaniecki, Socjologia wychowania, t. I: Wychowujące społeczeństwo, Warszawa 1973. Patrz: S. Kowalski, Wychowawcze funkcjonowanie społeczeństwa, „Neodidagmata” 1989, t. XIX. 
a więc międzypokoleniowym, cech identyfikujących system społeczny wobec innych tego rodzaju systemów, co określa się czasami mianem oznak tożsamości narodowej i/lub państwowej konkretnego systemu społecznego ${ }^{16}$. Ponadto podsystem kulturowy dysponuje mechanizmem, który w teorii socjologicznej systemów społecznych traktuje się jako taki, który strzeże system społeczny przed utratą swojej historycznej tożsamości, a który w zasadzie jest permanentnie poddawany modyfikacji w podsystemie sprawowania władzy wskutek upolityczniania owej historycznej tożsamości (w procedurze decyzyjnej tego podsystemu) ${ }^{17}$.

Z uruchamianiem i efektywnym przebiegiem mechanizmu wychowawczego (socjalizacyjnego) w zasadzie nie ma większego problemu, gdy ład społeczny konkretnego społeczeństwa państwowego zachowuje swoją identyczność przynajmniej przez kilka pokoleń i w swoich zasadniczych wymiarach (aspektach), takich jak:

- aksjonormatywny (wartości i forma ich konkretyzacji, taka jak obyczaj, prawo, moda);

- polityczny (decyzyjnym, ustrojowym);

- organizacyjny (stan i zasięg integracji struktur) czy

- światopoglądowy (dominująca - obowiązkowa w społeczeństwie narracja w opisie i objaśnianiu świata)

oraz ujawnia wysoki poziom integracji i społecznie akceptowanej dyferencjacji (np. klasowej, stanowej czy kastowej).

Przez setki (a nawet tysiące) lat taki stan rzeczy zyskiwały i utrwalały społeczeństwa państwowe o scentralizowanych, autokratycznych formach sprawowania władzy, wytwarzające i pielęgnujące uzasadniające je kultury religijne - jeśli przybierały one postać zinstytucjonalizowaną i w wysokim stopniu zintegrowaną z owymi pod-

${ }^{16}$ Globalne systemy społeczne mogą być identyfikowane jako narodowe i/lub jako państwowe, względnie jako jedne i drugie, w przypadku gdy organizacja życia społecznego, zwana państwem, obejmuje swoimi ramami społeczności obywateli identyfikujących się z jednym konkretnym narodem. Odrębną kwestią jest wybór kryteriów, na podstawie których następuje identyfikacja osób reprezentujących dany naród. Patrz m.in. S. Ossowski, O ojczyźnie i narodzie, Warszawa 1984; A. Kłoskowska, Skąd i po co naród?, „Znak” 1997, nr 3 (cały ten numer poświęcony jest problematyce narodu); P. Rybicki, Naród i państwo. Z rozważań nad relacją między dwiema postaciami wielkiej społeczności, [w:] Naród, kultura, osobowość. Księga poświęcona Profesorowi Józefowi Chałasińskiemu, Wrocław 1983; A. Bielewska, Tożsamość narodowa jako tożsamość terytorialna w kontekście migracji, Warszawa 2019.

17 Trudno poza tak zwanymi społeczeństwami pierwotnymi wskazać takie, w których konsekwentnie z pokolenia na pokolenie utrwala się względnie jednolitą koncepcję tego kto - jakie kategorie społeczne tworzą jego zasadniczy trzon, identyfikujący konkretne społeczeństwo wobec innych i kto w nim obecny może do tej roli aspirować. I po spełnieniu jakich warunków. Przez setki lat jedyną kategorią społeczną identyfikowaną z narodem polskim i państwem polskim była szlachta, aczkolwiek w pierwszej Rzeczpospolitej odrębny niejako status w ówczesnym państwie unijnym miała szlachta ruska, litewska, ukraińska czy tatarska. 
systemami sprawowania władzy (Egipt, Starożytna Grecja, Rzym, Europa chrześcijańska, Azja muzułmańska i hinduistyczna, państwo izraelskie i diaspora).

Zdarzeniami historycznymi, które podważyły ten utrwalony historycznie porządek, przynajmniej w części społeczeństw nowożytnych, była na kontynencie europejskim Komuna Paryska, a amerykańskim - wojna secesyjna, inicjując, zmieniony wobec tego tradycyjnego, porządek społeczny określany mianem demokratycznego - kształtowany i utrwalany ładem konstytucyjnym, wynegocjowanym i zaakceptowanym przez znaczące politycznie $\mathrm{w}$ danym społeczeństwie podmioty stanowiące i sprawujące władzę ${ }^{18}$. Porządek ów, jeśli jest faktycznie praktykowany, a nie tylko deklarowany, „odczarowal” fatalistyczną interpretację doświadczanych przez społeczeństwa problemów, kierując uwagę znacznej części współtworzących je struktur i kategorii osób społecznych ku poszukiwaniu ich „ziemskich” przyczyn i zwłaszcza konsekwencji.

Taką identyfikację i interpretację w tych społeczeństwach zyskał także społeczny problem wychowania, pojmowany jako:

- funkcja społecznego podsystemu wychowania ${ }^{19}$;

- swoiście pojęte pole praktyki społecznej ${ }^{20}$;

- społeczny wysiłek zmierzający do zrealizowania zadania przygotowania kolejnych pokoleń, $w$ warunkach gwarantujących ich egzystencjalną pomyślność, do kompetentnego i umotywowanego podjęcia przez nie i pełnienia ról na miarę społecznych oczekiwań wyznaczanych nie tylko doświadczeniem historycznym, wymogami struktury społecznej, lecz przede wszystkim wyzwaniami cywilizacyjnymi nieomal gruntownie zmieniającymi warunki egzystencjalne całych społeczeństw (uprzemysłowienie, usieciowienie) i ich (nie)spodziewaną a sygnalizowaną tymi warunkami perspektywę $e^{21}$.

${ }^{18} \mathrm{~W}$ swojej genezie porządek ów - jak wiadomo - sięga do czasów demokratycznie rządzonego państwa-miasta ateńskiego w połowie tysiąclecia przed naszą erą.

19 Patrz m.in.: S. Kowalski, Wychowawcze funkcjonowanie społeczeństwa..., op. cit. i tegoż: Systemy oświatowe scentralizowane i zdecentralizowane w świetle wyników badań M.S. Archer, „Socjologia Wychowania" 1984, t. V. Porównaj także: E. Syrek, Wychowanie jako przedmiot analiz pedagogiki społecznej i socjologii wychowania, Katowice 1987.

${ }^{20}$ Np.: E. Marynowicz-Hetka, Pedagogika społeczna. Pojmowanie aktywności w polu praktyki, Łódź 2019. Porównaj także z tekstami w pracy zbiorowej pod red. A. Walczak i in., Pedagogika społeczna. Spotkania, trwanie i zmienność, pogranicza, Łódź 2020.

${ }^{21}$ Świetnie to społeczne oczekiwanie żywione wobec podsystemu wychowawczego dokumentowały w swoim czasie raporty o stanie oświaty, m.in.: J. Szczepański (przew.), Raport o stanie oświaty w PRL, Warszawa 1973; E. Faure i in., Uczyć się aby być, Warszawa 1975; J.W. Botkin, M. Elmandjra, M. Malitza, Uczyć się bez granic, Warszawa 1982; Komisja Europejska, Biała księga kształcenia i doskonalenia zawodowego, Warszawa 1997; J. Delors, Edukacja. Jest w niej ukryty skarb, Warszawa 1998; F. Mayor, Przyszłość świata, Warszawa 2001 i kilka innych. A w początkach XXI wieku m.in. np. monografia pod red. H. Laudera i in., Education, Globlization and Social Change, Oxford 2006. 
Jest oczywistym to, iż przeobrażenia ładu społecznego w społeczeństwach cywilizacji przemysłowej w kierunku jego demokratyzacji nie następowały gwałtownie w czasie, a tym bardziej kompletnie, raczej przybierając postać sukcesywnego gromadzenia doświadczenia społecznego w osiąganiu pomyślnego rozwiązywania tego problemu i optymalizowania samego mechanizmu wychowawczego - socjalizacyjnego - poprzez doskonalenie jego funkcji, takich jak: kształcenie ogólne i zawodowe, gwarantowanie bezpieczeństwa egzystencjalnego dla dorastających pokoleń, sprawowanie kontroli wychowawczej, organizowanie czasu wolnego dzieci i młodzieży, diagnozowanie postępów w procesie uspołeczniania i dokonywanie stosownej do ich obrazu selekcji ${ }^{22}$.

W przekroju ostatniego stulecia, jako pedagodzy, obserwowaliśmy wzmożone i pomyślne starania podejmowane $\mathrm{w}$ systemie sprawowania władzy w kierunku objęcia wszystkich pokoleń, i w ich kompletnej reprezentacji, obowiązkową i w znacznej mierze zdemokratyzowaną edukacją szkolnąą, jednak nie zawsze i nie wszędzie realizowaną z satysfakcjonującym skutkiem, mimo podejmowania prób jej sukcesywnego - organizacyjnego doskonalenia, merytorycznego unowocześniania i upowszechniania na coraz wyższym szczeblu jej świadczenia. Działania te nie przynoszą spodziewanych efektów z rozmaitych powodów, między innymi i tego, że systemy oświatowe nie zawsze i nie wszędzie traktowane są przez polityków jako środki awansu cywilizacyjnego kolejnych pokoleń, lecz jako instrumenty realizacji celów politycznych, stąd przeważnie poddawane radykalnej, lecz nieskutecznej krytyce, upominającej się o przydawanie realizowanej w nim edukacji wartościowej poznawczo i biograficznie postaci, wyzbywającej się znamion symbolicznej przemocy, odpartyjnionej i odetatyzowanej ${ }^{24}$.

Wszystkie tego rodzaju monografie w zasadzie utożsamiają społeczny system wychowania z organizacją i funkcjonowaniem zinstytucjonalizowanego podsystemu oświaty, wskazując jedynie (czasami) na jego niektóre pozaoświatowe uwarunkowania i procesy towarzyszące powszechnie realizowanej edukacji kolejnych pokoleń do oczekujących je zadań w okresie ich dorosłości.. Pomyślne spełnianie tej powinności niepomiernie komplikuje znaczna nieprzewidywalność perspektywy społecznej. Np. B. Majerek, Niepewność w społeczeństwie wspótczesnym. Studium socjopedagogiczne, Kraków 2018.

${ }^{22}$ Mam tu na uwadze zwłaszcza jego diagnostyczno-selekcyjną funkcję sygnalizującą ograniczenia, jak dotychczas, w osiąganiu spodziewanej czy tylko postulowanej egalitaryzacji kształcenia kolejnych pokoleń w ich dostępie do wartościowej edukacji i demokratyzację szansy stratyfikacyjnej po jej ukończeniu. M.in. o tym problemie i jego konsekwencjach: G. Standing, Prekariat. Nowa niebezpieczna klasa, Warszawa 2014. Aspekt stratyfikacyjny np.: J. Modrzewski, Impulsy edukacyjne $w$ (re)konstrukcji struktury nie tylko społeczeństwa polskiego, „Studia Edukacyjne” 2013, nr 24. O ten aspekt demokratyzacji kształcenia dopominali się niejednokrotnie w swojej twórczości pedagodzy społeczni i socjolodzy wychowania, edukacji, a współcześnie np.: S. Kowalski, T. Pilch, W. Theiss, A. Radziewicz-Winnicki, Z. Kwieciński, M. Szymański, Z. Melosik czy B. Śliwerski.

${ }_{23}$ Patrz m.in.: A. Sawisz, Szkoła a system społeczny, Warszawa 1989.

${ }^{24}$ Warto przypominać w tym względzie znaczny dorobek światowej, ale i rodzimej pedagogiki krytycznej (np. liczne prace Z. Kwiecińskiego i wydawane z Jego inicjatywy) oraz krytyczną orienta- 
$\mathrm{W}$ parze $\mathrm{z}$ tymi staraniami postępuje, aczkolwiek jeszcze $\mathrm{w}$ wielce niedostatecznym wymiarze, praktyka tworzenia lub lekceważenia warunków bezpieczeństwa egzystencjalnego dorastających pokoleń i nie jest ona dostatecznie „monitorowana" przez polityków, samorządy i pedagogów, a tym bardziej kompleksowo projektowana i inicjowana ${ }^{25}$. To jeden $\mathrm{z}$ podstawowych wymogów pomyślnego i powszechnego rozwiązywania tak szeroko pojmowanego, społecznego problemu wychowania. Bezpieczeństwo egzystencjalne - przezwyciężające biedę, chroniące fizycznie (warunki socjalne, higiena, profilaktyka zdrowotna, terapia medyczna, kompensacja trwałych dysfunkcji ciała, ekologia środowiska ${ }^{26}$ itp.) i psychicznie (emocjonalnie) kolejne fale generacyjne, to zasadniczy warunek i wyzwanie dla społeczeństwa wychowującego, zwłaszcza zaniedbującego swoje w tym względzie powinności ${ }^{27}$. Skala zaniedbań i nieporadności w tym względzie, mimo niewąt-

cję teoretyczno-metodologiczną w refleksji socjologicznej w ogóle, a w socjologii wychowania i edukacji w szczególności. Zob. np.: D. Kellner, Critical Theory. Marxism, and Modernity, Baltimore1989; H.A. Giroux, P.L. McLaren (red.), Critical Pedagogy, the State, and Cultural Struggle, New York 1989. O niedostatkach współczesnej zinstytucjonalizowanej edukacji pisałem w: J. Modrzewski, Edukacja utowarowiona. Pułapki komercjalizacji edukacji zinstytucjonalizowanej, [w:] J. Piekarski, T. Pilch, W. Theiss, D. Urbaniak-Zając (red.), Edukacja społeczna wobec problemów współczesnego człowieka i społeczeństwa, Łódź 2010. Tragiczną ilustracją nieporadności decyzyjnej pedagogów (ekspertów oświatowych) mogą być losy polskiego systemu szkolnego poddawanego w ostatnim czasie właśnie politycznej manipulacji, deprecjacji merytorycznej i organizacyjnej. K. Marzec-Holka, A. Rutkowska (red.), Małe szkoły w województwie kujawsko-pomorskim. Studium pedagogiczno-socjologiczne, Bydgoszcz 2012.

${ }^{25}$ Gdyby pomijać lub traktować szczególnie problem tzw. dzieci i młodzieży ulicy, na ulicy, uzależnionej, niewolniczo wykorzystywanej, zdemoralizowanej i przestępczej, który jest właśnie efektem skrajnego zaniedbania jednej ze szczegółowych funkcji owego społecznego systemu wychowania, to pozostają jeszcze rzesze dzieci i młodzieży doświadczającej biedy rodzinnej - społecznie skrywanej, opuszczonej, izolującej się, wsiąkającej w cyberprzestrzeń, wędrującej i zalegającej w przytuliskach. To również zaniedbania $\mathrm{w}$ realizacji funkcji ogólnie określanej jako opiekuńcza, która mieści się właśnie w tak szeroko pojętym wychowaniu jako społecznej praktyce, społecznym wysiłku zmierzającym do przygotowywania kolejnych pokoleń ku dorosłości i ich w tej kategorii wiekowej reprodukcyjnym zobowiązaniu. O takie kompleksowe pedagogiczne „spojrzenie” na tę problematykę upomina się m.in. E. Marynowicz-Hetka w swojej ostatnio wydanej monografii: Pedagogika społeczna. Pojmowanie aktywności..., op. cit. Problematyka ta, wymagająca takiego kompleksowego spojrzenia pedagogicznego na kondycję egzystencjalną m.in. dorastającego pokolenia, stanowiła zasadniczy argument konstruowania inspirujących poznawczo rozstrzygnięć w redakcyjnej dyskusji czasopisma „Societas/Communitas" nad potrzebą pedagogizacji życia społecznego z perspektywy socjologicznej i pedagogicznej. Patrz: M. Czyżewski, E. Marynowicz-Hetka, G. Woroniecka, Pedagogizacja życia społecznego, „Societas/Communitas” 2013, nr 2 (16).

${ }^{26}$ M.in.: P. Matczak, Problemy ekologiczne jako problemy społeczne, Poznań 2002; E. Kośmicki, Środowisko w ujęciu ekologiczno-ekonomicznym, [w:] J. Modrzewski, A. Matysiak-Błaszczyk, E. Włodarczyk (red.), Środowiska uczestnictwa społecznego jednostek, kategorii i grup (doświadczenia socjalizacyjne i biograficzne), Poznań 2018.

${ }_{27}$ Świetnie zostało owo zaniedbanie ukazane w znakomitym eseju pedagogicznym T. Pilcha, Państwo i społeczeństwo - przedmiot refleksji i troski pedagogiki społecznej, [w:] E. Jarosz (red.), Wie- 
pliwie podejmowania starań, $w$ dalszym ciągu jeszcze poraża swoimi rozmiarami i dynamiką (dzieci i młodzież na ulicy i ulicy, dzieci doświadczające biedy, przemocy, osierocenia i utraty zdrowia i życia, drastyczny spadek dzietności, milionowe emigracje Polaków ${ }^{28}$.

Tak szeroko pojęte wychowanie (społeczny problem wychowania) obejmuje także powinność sygnalizowaną w odnośnych koncepcjach teoretycznych jako spełnianie funkcji kontroli społecznej o znamionach wychowawczejej $\mathrm{i}$ jej (nie)pomyślna realizacja jest kolejnym istotnym warunkiem (nie)rozwiązywania społecznego problemu wychowania w wymiarze ogólnospołecznym, jak i lokalnym, a zaniedbania w tym względzie kwalifikuje się jako przejaw dysfunkcjonalności społeczeństwa, jako swoistej funkcjonalnej całości i jej terytorialnych reprezentacji ${ }^{30}$.

Może być ona, owa kontrola wychowawcza, orientowana czy nastawiona - jak w społeczeństwach pierwotnych i rolniczych - na stanowienie i respektowanie norm i wartości tradycyjnych, utrwalonych w obyczaju czy w tak zwanych „naturalnych sposobach postępowania w gromadzie", jak je nazwali tłumacze słynnej monografii W.G. Sumnera ${ }^{31}$. Może być ona efektem troski społeczności o zachowanie i wzmacnianie więzi lokalnych, sąsiedzkich, rodzinno-rodowych, parafialnych, zrzeszeniowych, wreszcie obywatelskich, lecz przede wszystkim winna egzekwować konsekwentnie respektowanie norm gwarantujących bezpieczeństwo witalne i biograficzne. W tym aspekcie rodzimy społeczny system wychowania jawi się jako znacznie dysfunkcjonalny, z trudem ograniczający destrukcyjne witalnie i biograficznie konsekwencje popadania dzieci i młodzieży w rozliczne uzależ-

lowymiarowość dobrostanu człowieka i społeczeństw, czyli o tym, jak szlachetne jest zdrowie. Księga jubileuszowa dedykowana Profesor Ewie Syrek, Katowice 2020.

${ }^{28}$ Zaangażowanie np. pedagogów społecznych i opiekuńczych uprawiających pedagogikę zdrowia, dziecka, młodzieży w diagnozowanie owych warunków czy aspektu społecznego problemu wychowania, a także pomyślane przez pedagogów i realizowane w praktyce działania zmierzające do łagodzenia, względnie rozwiązywania tego aspektu problemu wychowawczego było i jest już znaczne, aczkolwiek niewspółmierne do potrzeb. Sygnalizują ją m.in. takie opracowania, jak: B. Adamczyk, Dzieci ulicy w Polsce i na świecie, Kraków 2015 i 2016; T. Pilch, Miliard dzieci bez szczęścia, [w:] E. Jarosz (red.), Dzieciństwo witraż bolesny, „Chowanna” 2010, t. 1 (34); K. Marzec-Holka, Przemoc seksualna wobec dziecka. Studium pedagogiczno-kryminologiczne, Kraków 2011; S. Trusz, M. Kwiecień, Społeczne piętno eurosieroctwa, Warszawa 2012; E. Syrek, Zdrowie i wychowanie a jakość życia. Perspektywy i humanistyczne orientacje poznawcze, Katowice 2008; G. Cęcelek, Sytuacja szkolna dziecka z rodziny ubogiej, Warszawa 2011; K. Marzec-Holka (red.), Kapitał społeczny a nierówności, kumulacja i redystrybucja, Bydgoszcz 2009.

${ }^{29}$ M.in.: S. Kowalski, Socjologia wychowania w zarysie, Warszawa 1974, r. IX.

${ }^{30} \mathrm{~Np}$.: W. Ambrozik, Wychowawcze funkcjonowanie średniego miasta uprzemystowionego. Analiza systemowa ze szczególnym uwzględnieniem funkcji samoregulujących, Poznań 1991; M. Dąbrowska-Bąk, K. Pawełek, Dysfunkcjonalność lokalnego społeczeństwa wychowującego, Poznań 2013. Zobacz także teksty w: W. Ambrozik, J. Modrzewski (red.), Stanisław Kowalski - pamięć postaci uczonego i kontynuacje jego dorobku, Poznań 2021.

31 W.G. Sumner, Naturalne sposoby postepowania w gromadzie, Warszawa 1995. 
nienia $^{32}$, demoralizacje ${ }^{33}$ i przestępczośćc ${ }^{34}$. Jedną z zasadniczych przyczyn niskiej wychowawczej sprawczości kontroli społecznej w wymiarze ogólnokrajowym i lokalnym, we współczesnym polskim „społeczeństwie (nie)wychowującym”, jest postępująca destrukcja władzy sądzenia i podwójne standardy w kwalifikacji zachowań społecznych zwolenników i krytyków władzy wykonawczej, a także arogancki styl jej sprawowania. Bez wątpienia wprowadza to trudny do pedagogicznego oszacowania tego stanu rzeczy chaos w systemie norm i wartości ${ }^{35}$. W tego rodzaju sytuacji kontrola społeczna traci swój wychowawczy walor, tworząc niebezpieczne egzystencjalnie precedensy ${ }^{36}$.

Znacznej modyfikacji ulega obraz i treść jeszcze jednej funkcji społecznego systemu wychowania, jaką jest organizacja czasu wolnego dzieci i młodzieży. Rozwój techniki komputerowej i technologii internetowej radykalnie zreorganizował proporcje czasu zajętego i czasu wolnego, przydając mu nowych form i trudnych do wyeliminowania pułapek, preferujących bierne w nim uczestnictwo i konsu-

${ }^{32}$ Np.: B. Fatyga. J. Rogala-Obłękowska, Style życia młodzieży a narkotyki, Warszawa 2002; L. Cierpiałkowska (red.), Oblicza współczesnych uzależnień, Poznań 2006; G. Adamczyk, M. Jeżowski, L. Smyczek, Postawy młodzieży szkół średnich wobec narkomanii, Lublin 2006; M. Abucewicz, Narkomania - problem społeczny w perspektywie konstruktywistycznej, Warszawa 2012; A. Kurzeja (red.), Uzależnienie od narkotyków. Od teorii do praktyki terapeutycznej, Warszawa 2012; M.Z. Jędrzejko, A. Taper, T. Kozłowski, Cyberzaburzenia, cyberuzależnienia, Warszawa-Ostrowiec Świętokrzyski 2020; M.Z. Jędrzejko, B.P. Rosik, M. Kowalski (red.), Uzależnienia behawioralne. Wybrane aspekty, Pułtusk-Warszawa 2015; E. Włodarczyk, Społeczny wymiar problemu alkoholowego kobiet. Obraz i instytucjonalne reakcje środowiska wielkomiejskiego, Poznań 2017; J. Modrzewski, E. Włodarczyk, Problem alkoholowy w doświadczeniu społecznym, „Chowanna” 2018, t. 2 (51) i wiele innych.

${ }^{33}$ Np.: B. Urban (red.), Dewiacje wśród młodzieży. Uwarunkowania i profilaktyka, Kraków 2001; B. Dzięcioł, Poza kontrola. Funkcjonowanie kontroli społecznej wobec dziecka w wielkim mieście, Poznań 2002; A. Minkiewicz (red.), Patologia społeczna wśród młodzieży. Stan, metody analizy i sposoby przeciwdziałania, Warszawa 2003; P. Szarszewski, Satanizm w Polsce, Warszawa 2004; M. Jędrzejewski, Subkultury a przemoc, Warszawa 2001; B. Urban, Zachowania dewiacyjne młodzieży w interakcjach rówieśniczych, Kraków 2005; I. Pospiszyl, R. Szczepanik (red.), Zachowania dewiacyjne dziewcząt i kobiet, Łódź 2007; J. Kurzępa, Młodzi, piękne i niedrodzy. Młodość w objęciach seksbiznesu, Kraków 2012; M. Michel, Gry uliczne. Wykluczenie społeczne w przestrzeni miejskiej. Perspektywa resocjalizacyjna, Kraków 2016; A. Matysiak-Błaszczyk, B. Jankowiak (red.), Kontrowersje wokót socjalizacji dziewcząt i kobiet, Poznań 2016.

${ }^{34}$ B. Urban, Zaburzenia w zachowaniu i przestępczość młodzieży, Kraków 2000; L. Wieczorek, Przestęczzość i demoralizacja nieletnich w Polsce w okresie transformacji ustrojowej, Katowice 2006; B. Gulla, M. Wysocka-Pleczyk (red.), Przestępczość nieletnich, Kraków 2009; K. Biel, Przestępczość dziewcząt. Rodzaje i uwarunkowania, Kraków 2012; K. Sawicki, Diady, kliki, gangi. Młodzież nieprzystosowana społecznie w perspektywie wspótczesnej pedagogiki resocjalizacyjnej, Białystok 2018 i wiele innych.

${ }^{35}$ O społecznym i podmiotowym znaczeniu respektowania w życiu społecznym wartości m.in.: P. Sztompka, Zaufanie. Fundament społeczeństwa, Kraków 2007; M. Bogunia-Borowska (red.), Fundamenty dobrego społeczeństwa. Wartości, Kraków 2015.

${ }^{36}$ Między innymi zjawisko i stan tak zwanego prawnego wykluczenia. Patrz np. A. Turska (red.), Prawo i wykluczenie. Studium empiryczne, Warszawa 2010. 
mencki styl życia ${ }^{37}$. Ograniczone środki finansowe władz lokalnych, decydujących o kondycji budżetowej szkolnictwa powszechnego w naszym kraju, znacznie, jeśli nie kompletnie, ograniczyły inicjatywność szkół powszechnych w organizowaniu czasu pozalekcyjnego i pozaszkolnego dzieci i młodzieży. Sytuację tę totalnie zdeprecjonował czas pandemii, wyzwalając trudne do oszacowania konsekwencje witalne i socjalizacyjne dzieci i młodzieży szkolnej ${ }^{38}$.

Pomyślne rozwiązywanie społecznego problemu wychowania wymaga więc spełnienia kilku podstawowych wymogów - warunków, które wskazaliśmy wyżej, właściwych dla społeczeństwa jako całości funkcjonującego w swojej płaszczyźnie wychowawczej - identyfikowanej w teorii socjologicznej jako społeczny system wychowania ${ }^{39}$. Ulega on sukcesywnej destrukcji w swoich podstawowych funkcjach, gdy społeczeństwo jako swoiście pojęty system ulega postępującej dez-

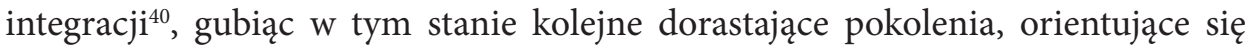
w doświadczanym przez siebie procesie socjalizacji ku wartościom i państwowej organizacji życia społecznego innych społeczeństw - podejmując życiowe decyzje swojej ku nim emigracji.

\section{Bibliografia}

Abucewicz M., Narkomania - problem społeczny w perspektywie konstruktywistycznej, Warszawa 2012.

Adamczyk B., Dzieci ulicy w Polsce i na świecie, Kraków 2015, 2016.

Adamczyk G., Jeżowski M., Smyczek L., Postawy młodzieży szkót średnich wobec narkomanii, Lublin 2006.

Ambrozik W., Wychowawcze funkcjonowanie średniego miasta uprzemysłowionego. Analiza systemowa ze szczególnym uwzględnieniem funkcji samoregulujących, Poznań 1991.

${ }^{37}$ M. Orłowska, Przymus bezczynności, Warszawa 2015; M. Orłowska, J.J. Błeszyński, Czas wolny jako środowisko życia. Perspektywa pedagogiczna, Warszawa 2016; G. Ritzer, Makdonaldyzacja społeczeństwa, Warszawa 2000; J.B. Schor, Born to Buy, New York 2004; M. Bogunia-Borowska, Dziecko w świecie mediów i konsumpcji, Kraków 2006; B. Barber, Skonsumowani. Jak rynek psuje dzieci, infantylizuje dorostych i połyka obywateli, Warszawa 2008; T. Szlendak, T. Kozłowski, Naga małpa przed telewizorem. Popkultura w świetle psychologii ewolucyjnej, Warszawa 2008; Z. Melosik, Kultura popularna i tożsamość młodzieży. W niewoli władzy i wolności, Kraków 2013.

${ }^{38} \mathrm{~Np}$. T. Wilk, Kultura i sztuka w szkolnej i środowiskowej edukacji młodzieży. Edukacyjne doświadczenia z przeszłości, realia teraźniejszości, perspektywa przyszłości, komputeropis w posiadaniu autora artykułu przekazany do druku, s. 523.

${ }^{39}$ Patrz S. Kowalski (red.), Funkcjonowanie systemu wychowawczego w środowisku, Wrocław 1974; także: K. Marzec-Holka, A. Wiłkomirska, A. Radziewicz-Winnicki, Nauki społeczne wobec zmiany - alternatywa scalania (inspiracje dla współczesnej pedagogiki), Warszawa 2018.

${ }^{40} \mathrm{~J}$. Modrzewski, Od pedagogiki środowiska ku pedagogice społeczeństwa obezwładnionego instytucja państwową, „Pedagogika Społeczna” 2018, nr 4. 
Ambrozik W., Modrzewski J. (red.), Stanisław Kowalski - pamięć postaci uczonego i kontynuacje jego dorobku, Poznań 2021.

Amsterdamski S., Nauka, [w:] A. Kłoskowska, S. Krzemień-Ojak (red.), Encyklopedia kultury polskiej XX wieku, Wrocław 1991.

Baert P., Carreira da Silva F., Teorie społeczne w XX wieku i dzisiaj, Kraków 2013.

Barber B., Skonsumowani. Jak rynek psuje dzieci, infantylizuje dorostych i połyka obywateli, Warszawa 2008.

Bauman Z., Socjalizm. Utopia w działaniu, Warszawa 2010.

Biel K., Przestępczość dziewcząt. Rodzaje i uwarunkowania, Kraków 2012.

Bielewska A., Tożsamość narodowa jako tożsamość terytorialna w kontekście migracji, Warszawa 2019.

Bogunia-Borowska M., Dziecko w świecie mediów i konsumpcji, Kraków 2006.

Bogunia-Borowska M. (red.), Fundamenty dobrego społeczeństwa. Wartości, Kraków 2015.

Boni K., Auroville. Miasto z marzeń, Warszawa 2020.

Botkin J.W., Elmandjra M., Malitza M., Uczyć się bez granic, Warszawa 1982.

Cęcelek G., Sytuacja szkolna dziecka z rodziny ubogiej, Warszawa 2011.

Cierpiałkowska L. (red.), Oblicza współczesnych uzależnień, Poznań 2006.

Cyrzan H., O potrzebie utopii, Toruń 2004.

Czyżewski M., Marynowicz-Hetka E., Woroniecka G., Pedagogizacja życia społecznego, „Societas/ Communitas" 2013, nr 2 (16).

Dahrendorf R., Klasy i konflikt klasowy w społeczeństwie przemysłowym, Kraków 2008.

Dąbrowska-Bąk M., Pawełek K., Dysfunkcjonalność lokalnego społeczeństwa wychowującego, Poznań 2013.

Delors J., Edukacja. Jest w niej ukryty skarb, Warszawa 1998.

Dzięcioł B., Poza kontrola. Funkcjonowanie kontroli społecznej wobec dziecka w wielkim mieście, Poznań 2002.

Fatyga B., Rogala-Obłękowska J., Style życia młodzieży a narkotyki, Warszawa 2002.

Faure E. i in., Uczyć się, aby być, Warszawa 1975.

Giroux H.A., McLaren P.L. (red.), Critical Pedagogy, the State, and Cultural Struggle, New York 1989.

Gulla B., Wysocka-Pleczyk M. (red.), Przestępczość nieletnich, Kraków 2009.

Habermas J., Teoria działania komunikacyjnego, Warszawa 1999.

Henslin J.M., Social Problems, Sixth edition, New Jersey 2003.

Jacyno M., Kultura indywidualizmu, Warszawa 2007.

Jasińska-Kania A. i in. (red.), Wspótczesne teorie socjologiczne, t. I i II, Warszawa 2006.

Jędrzejewski M., Subkultury a przemoc, Warszawa 2001.

Jędrzejko M.Z., Rosik B.P., Kowalski M. (red.), Uzależnienia behawioralne. Wybrane aspekty, Pultusk-Warszawa 2015.

Jędrzejko M.Z., Taper A., Kozłowski T., Cyberzaburzenia, cyberuzależnienia, Warszawa-Ostrowiec Świętokrzyski 2020.

Kellner D., Critical Theory. Marxism, and Modernity, Baltimore 1989.

Kłoskowska A., Skąd i po co naród?, „Znak” 1997, nr 3.

Komisja Europejska, Biała księga kształcenia i doskonalenia zawodowego, Warszawa 1997.

Kośmicki E., Środowisko w ujęciu ekologiczno-ekonomicznym, [w:] J. Modrzewski, A. Matysiak-Błaszczyk, E. Włodarczyk (red.), Środowiska uczestnictwa społecznego jednostek, kategorii i grup (doświadczenia socjalizacyjne i biograficzne), Poznań 2018.

Kowalski S., Socjologia wychowania w zarysie, Warszawa 1974. 
Kowalski S., Systemy oświatowe scentralizowane i zdecentralizowane w świetle wyników badań M.S. Archer, „Socjologia Wychowania” 1984, t. V.

Kowalski S., Wychowawcze funkcjonowanie społeczeństwa, „Neodidagmata” 1989, t. XIX.

Kowalski S. (red.), Funkcjonowanie systemu wychowawczego w środowisku, Wrocław 1974.

Kropotkin P., Pomoc wzajemna, Poznań 2006.

Kurzeja A. (red.), Uzależnienie od narkotyków. Od teorii do praktyki terapeutycznej, Warszawa 2012.

Kurzępa J., Młodzi, piękne i niedrodzy. Młodość w objęciach seksbiznesu, Kraków 2012.

Lauder H., Brown Ph., Dillabough J.-A., Halsey A.H. (red.), Education, Globlization and Social Change, Oxford 2006.

Luhmann N., Systemy społeczne, Kraków 2007.

Macionis J.J., Social Problems, Upper Saddle River, NJ 2011.

Majerek B., Niepewność w społeczeństwie współczesnym. Studium socjopedagogiczne, Kraków 2018.

Malikowski M. (red.), Problemy społeczne w okresie zmian systemowych w Polsce, Rzeszów 1997.

Manterys A., Mucha J. (red.), Nowe perspektywy teorii socjologicznej. Wybór tekstów, Kraków 2009.

Marynowicz-Hetka E., Pedagogika społeczna. Pojmowanie aktywności w polu praktyki, Łódź 2019.

Marzec-Holka K., Przemoc seksualna wobec dziecka. Studium pedagogiczno-kryminologiczne, Kraków 2011.

Marzec-Holka K. (red.), Kapitał społeczny a nierówności, kumulacja i redystrybucja, Bydgoszcz 2009.

Marzec-Holka K., Rutkowska A. (red.), Małe szkoły w województwie kujawsko-pomorskim. Studium pedagogiczno-socjologiczne, Bydgoszcz 2012.

Marzec-Holka K., Wiłkomirska A., Radziewicz-Winnicki A., Nauki społeczne wobec zmiany - alternatywa scalania (inspiracje dla współczesnej pedagogiki), Warszawa 2018.

Matczak P., Problemy ekologiczne jako problemy społeczne, Poznań 2002.

Matysiak-Błaszczyk A., Jankowiak B. (red.), Kontrowersje wokół socjalizacji dziewcząt i kobiet, Poznań 2016.

Mayor F., Przyszłość świata, Warszawa 2001.

Melosik Z., Kultura popularna i tożsamość młodzieży. W niewoli władzy i wolności, Kraków 2013.

Merton R.K., Nisbet R. (red.), Contemporary Social Problems, New York 1971.

Michel M., Gry uliczne. Wykluczenie społeczne w przestrzeni miejskiej. Perspektywa resocjalizacyjna, Kraków 2016.

Minkiewicz A. (red.), Patologia społeczna wśród młodzieży. Stan, metody analizy i sposoby przeciwdziałania, Warszawa 2003.

Misztal B., Teoria socjologiczna a praktyka społeczna, Kraków 2000.

Miś L., Problemy społeczne Grupy Wyszehradzkiej, Kraków 2019.

Miś L., Problemy społeczne. Teoria, metodologia, badania, Kraków 2007.

Miś L., Nóżka M., Smagacz-Poziemska M., Nasze problemy. Bieda i bezrobocie we wspótczesnym społeczeństwie polskim, Kraków 2011.

Modrzewski J., Edukacja utowarowiona. Pułapki komercjalizacji edukacji zinstytucjonalizowanej, [w:] J. Piekarski, T. Pilch, W. Theiss, D. Urbaniak-Zając (red.), Edukacja społeczna wobec problemów współczesnego człowieka i społeczeństwa, Łódź 2010.

Modrzewski J., Impulsy edukacyjne w (re)konstrukcji struktury nie tylko społeczeństwa polskiego, „Studia Edukacyjne" 2013, nr 24.

Modrzewski J., Od pedagogiki środowiska ku pedagogice społeczeństwa obezwładnionego instytucja państwowa, „Pedagogika Społeczna” 2018, nr 4. 
Modrzewski J., Społeczeństwo, [w:] T. Pilch (red.), Encyklopedia Pedagogiczna XXI wieku, t. 5, Warszawa 2005.

Modrzewski J., Studia i szkice socjopedagogiczne. Aktualia, Kalisz-Poznań 2012.

Modrzewski J., Z(dez)integrowanie społeczeństwa - istota zjawiska i problemu w perspektywie strukturalno-funkcjonalnej, „Pedagogika Społeczna” 2017, nr 4.

Modrzewski J., Włodarczyk E., Problem alkoholowy w doświadczeniu społecznym, „Chowanna” 2018, t. 2 (51).

Mouffe Ch., Paradoks demokracji, Wrocław 2005.

Neubeck K.J., Neubeck M.A., Social Problems: A Critical Approach, New York 1997.

Nowak A., Wysocka E., Problemy i zagrożenia społeczne we wspótczesnym świecie, Katowice 2001.

Orłowska M., Przymus bezczynności, Warszawa 2015.

Orłowska M., Błeszyński J.J., Czas wolny jako środowisko życia. Perspektywa pedagogiczna, Warszawa 2016.

Ossowski S., O ojczyźnie i narodzie, Warszawa 1984.

Parsons T., System społeczny, Kraków 2009.

Pilch T., Miliard dzieci bez szczęścia, [w:] E. Jarosz (red.), Dzieciństwo witraż bolesny, „Chowanna” 2010, t. 1 (34).

Pilch T., Państwo i społeczeństwo - przedmiot refleksji i troski pedagogiki społecznej, [w:] E. Jarosz (red.), Wielowymiarowość dobrostanu człowieka i społeczeństw, czyli o tym, jak szlachetne jest zdrowie. Ksiega jubileuszowa dedykowana Profesor Ewie Syrek, Katowice 2020.

Pospiszyl I., Szczepanik R. (red.), Zachowania dewiacyjne dziewcząt i kobiet, Łódź 2007.

Ritzer G., Makdonaldyzacja społeczeństwa, Warszawa 2000.

Rubington E., Weinberg M.S. (red.), The Study of Social Problems: Seven Perspectives, New York 2003.

Rybicki P., Naród i państwo. Z rozważań nad relacja między dwiema postaciami wielkiej społeczności, [w:] Naród, kultura, osobowość. Księga poświęcona Profesorowi Józefowi Chałasińskiemu, Wroclaw 1983.

Sawicki K., Diady, kliki, gangi. Młodzież nieprzystosowana społecznie w perspektywie współczesnej pedagogiki resocjalizacyjnej, Białystok 2018.

Sawisz A., Szkoła a system społeczny, Warszawa 1989.

Schor J.B., Born to Buy, New York 2004.

Scott J.C., Jak udomowiono człowieka. U początków historii pierwszych państw, przekł. F. Tryl, Warszawa 2020.

Sobecki M., Misiejuk D., Muszyńska J., Bajkowski T. (red.), Człowiek pogranicza. Wyzwania humanistycznej edukacji, Białystok 2019.

Standing G., Prekariat. Nowa niebezpieczna klasa, Warszawa 2014.

Sumner W.G., Naturalne sposoby postępowania w gromadzie, Warszawa 1995.

Syrek E., Wychowanie jako przedmiot analiz pedagogiki społecznej i socjologii wychowania, Katowice 1987.

Syrek E., Zdrowie i wychowanie a jakość życia. Perspektywy i humanistyczne orientacje poznawcze, Katowice 2008.

Szacki J., Historia myśli socjologicznej, Warszawa 2021.

Szarszewski P., Satanizm w Polsce, Warszawa 2004.

Szczepański J., Raport o stanie oświaty w PRL, Warszawa 1973.

Szlendak T., Kozłowski T., Naga małpa przed telewizorem. Popkultura w świetle psychologii ewolucyjnej, Warszawa 2008. 
Szmatka J., Jednostka i społeczeństwo. O zależności zjawisk indywidualnych od społecznych, Warszawa 1980.

Sztompka P., Zaufanie. Fundament społeczeństwa, Kraków 2007.

Theiss M. (red.), Lokalne obywatelstwo społeczne w polityce społecznej. Przykład wychowania przedszkolnego, Warszawa 2018.

Trusz S., Kwiecień M., Społeczne piętno eurosieroctwa, Warszawa 2012.

Turska A. (red.), Prawo i wykluczenie. Studium empiryczne, Warszawa 2010.

Urban B., Zaburzenia w zachowaniu i przestępczość młodzieży, Kraków 2000.

Urban B., Zachowania dewiacyjne młodzieży w interakcjach rówieśniczych, Kraków 2005.

Urban B. (red.), Dewiacje wśród młodzieży. Uwarunkowania i profilaktyka, Kraków 2001.

Walczak A. i in. (red.), Pedagogika społeczna. Spotkania, trwanie i zmienność, pogranicza, Łódź 2020.

Weber M., Economy and Society, Berkeley, CA 1978.

Wieczorek L., Przestępczość i demoralizacja nieletnich $w$ Polsce $w$ okresie transformacji ustrojowej, Katowice 2006.

Wilk T., Kultura i sztuka w szkolnej i środowiskowej edukacji młodzieży. Edukacyjne doświadczenia z przeszłości, realia teraźniejszości, perspektywa przyszłości, komputeropis w posiadaniu autora artykułu przekazany do druku.

Włodarczyk E., Społeczny wymiar problemu alkoholowego kobiet. Obraz i instytucjonalne reakcje środowiska wielkomiejskiego, Poznań 2017.

Ziółkowski M., Teoria socjologiczna a transformacja społeczeństwa polskiego, Warszawa 2015.

Znaniecki F., Nauki o kulturze, Warszawa 1971.

Znaniecki F., Socjologia wychowania, t. I: Wychowujace społeczeństwo, Warszawa 1973. 